\title{
Globalization Tropes in Films: A Focus on Crazy Rich Asians
}

Nikhilesh Dholakia

University of Rhode Island

Deniz Atik

University of Texas Rio Grande Valley

Follow this and additional works at: https://digitalcommons.uri.edu/mgdr

Part of the Anthropology Commons, Economics Commons, Film and Media Studies Commons, Marketing Commons, Other Business Commons, and the Sociology Commons

\section{Recommended Citation}

Dholakia, Nikhilesh and Atik, Deniz (2019) "Globalization Tropes in Films: A Focus on Crazy Rich Asians," Markets, Globalization \& Development Review. Vol. 4: No. 3, Article 1.

DOI: 10.23860/MGDR-2019-04-03-01

Available at: https://digitalcommons.uri.edu/mgdr/vol4/iss3/1

This Editorial is brought to you for free and open access by DigitalCommons@URI. It has been accepted for inclusion in Markets, Globalization \& Development Review by an authorized editor of DigitalCommons@URI. For more information, please contact digitalcommons-group@uri.edu. 
Globalization Tropes in Films: A Focus on Crazy Rich Asians

\section{Markets, Globalization \& Development Review}
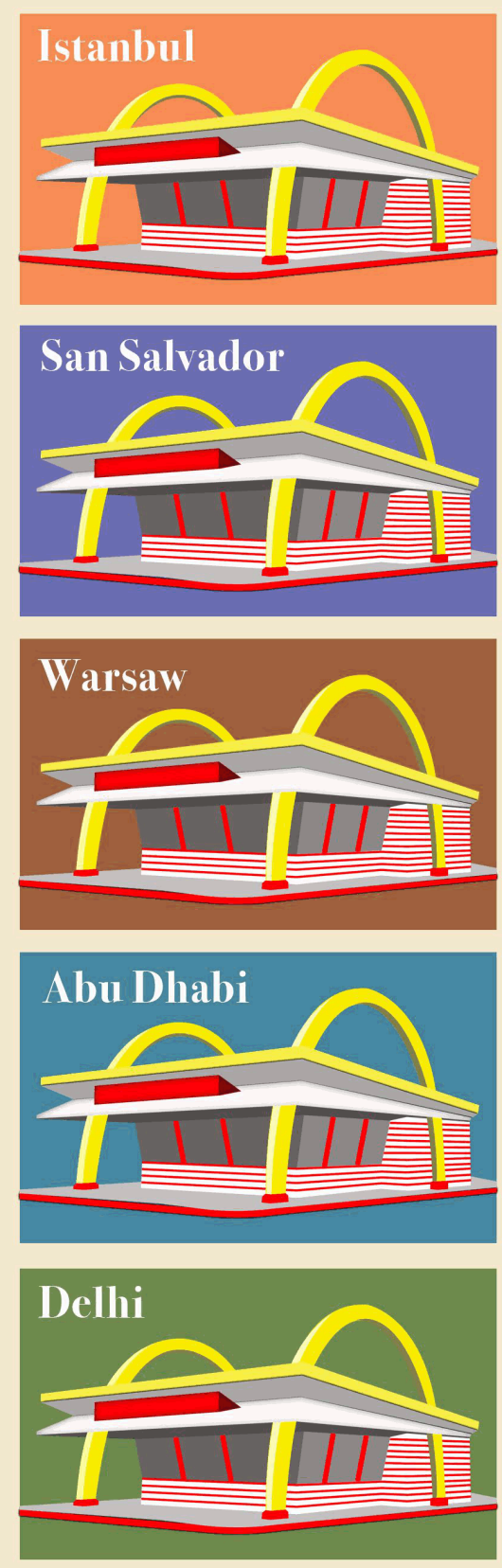
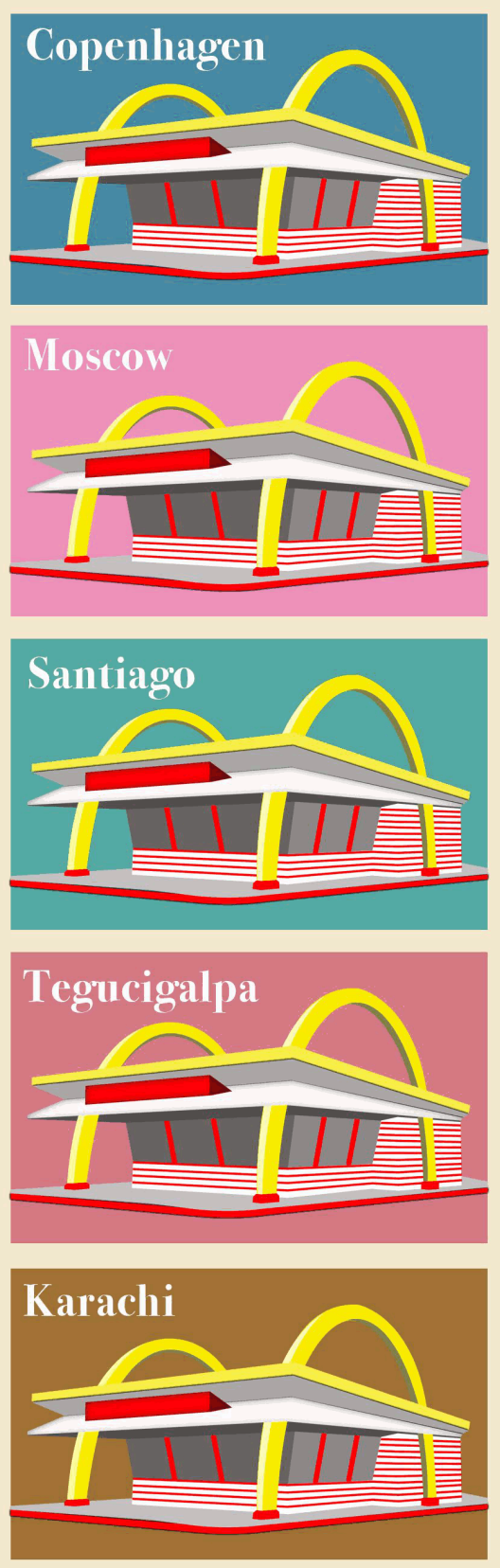
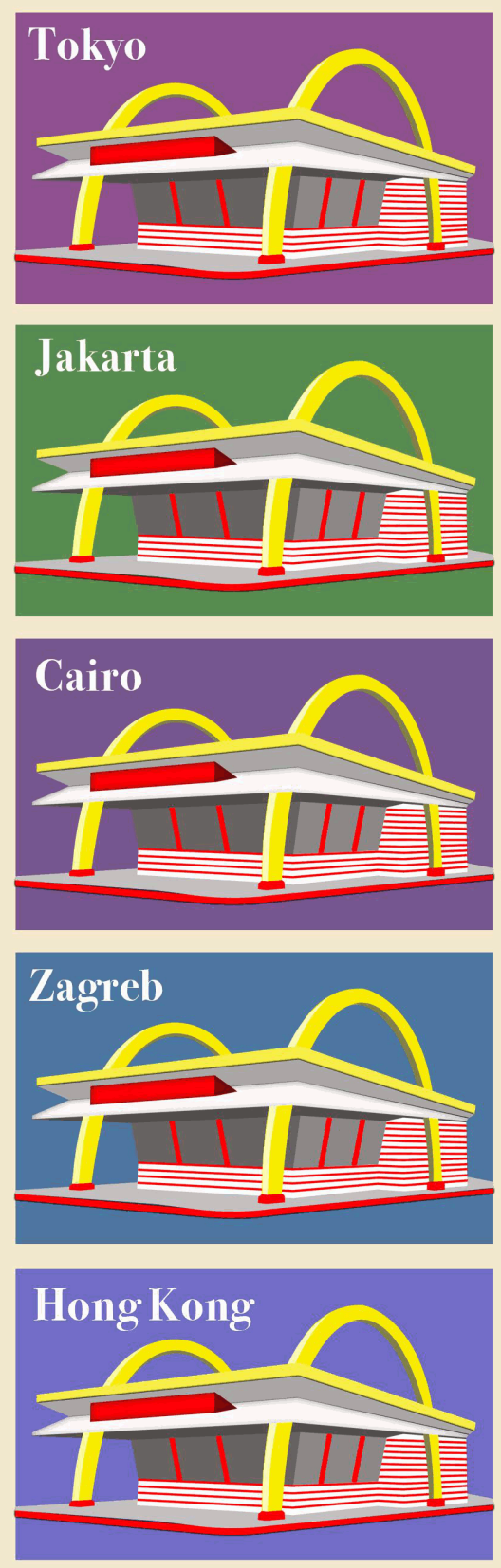

This editorial is available in Markets, Globalization \& Development Review: https://digitalcommons.uri.edu/mgdr/ vol4/iss $3 / 1$ 


\section{Globalization Tropes in Films: A Focus on Crazy Rich Asians}

\section{Introduction}

Art of course does imitate Life; and occasionally, Life imitates Art. In the cinematic form, art can present messages in powerful and engaging (or, in some cases, repelling) ways. Art as film can subvert, distort, celebrate, berate, aggrandize and challenge.

At MGDR, we are cognizant of the power of audiovisual media like films. Therefore, in addition to research articles and intellectual commentaries, we strive to employ the filmic window (a well as windows to other media) to peek into globalization, marketing, and development phenomena. For example, for quite some time now, the review of the documentary film about fast fashion, written by Ozdamar-Ertekin (2017), has remained the most downloaded article from MGDR. Also, as of the last quarter of 2019, the two reviews of the movie Black Panther - by Eckhardt (2018) and Bowles (2018) - feature in the 'most popular downloads' list of MGDR articles.

We have also featured other movie-based insights into contemporary problems of globalization, markets and development. For example, in the pages of MGDR, Hazera (2017) has reviewed the movie The Founder, which sheds light into the genius as well as the ruthlessness of the strategy that created the McDonald's fast-food mega-franchise - a business that, incidentally, also forms the basis for the satirical-critical cover design of MGDR by artist Linda Lewis. Using parallels to the megahit superhero movies Avengers: Infinity Wars and Avengers: Endgame, in a forthcoming piece, David Boje (2019) takes a bitingly critical look at the global corporate giants in the water business. Boje finds that these firms are pushing our planet and more than half its population toward a gradual and parched Water Apocalypse, even as they deploy creative strategies to peddle clean water to the super-rich slivers of the population.

Learning from and encouraged by the impacts of film-based windows into globalization phenomena, in this issue of MGDR, we have focused on the film Crazy Rich Asians. In the popular press, the movie has been hailed as a major cultural point of departure for Hollywood as well as panned as just an Asian-themed romantic comedy that celebrates the super-rich of Asia. The buzz around this movie does, however, indicate a slight bend in the curve of the geopolitics of the globalization discourse and hence our decision to feature a number of academically insightful reviews of this movie in the current issue. 


\section{Brief Background of the CRA Movie}

Crazy Rich Asians (2018) is a romantic comedy performed by an almost all-Asian cast directed by Jon M. Chu, based on a novel of Kevin Kwan on the Asian elites. The story develops around a middle-class ChineseAmerican woman, a young professor of economics at NYU, travelling to Singapore with her boyfriend, for a wedding party. Only after being introduced to the ultra-rich family, she realizes how wealthy her boyfriend is. At first, she is not welcomed to the family, especially by her boyfriend's mother, as the young professor does not possess similar wealth and sociocultural background. The movie unfolds around her struggles between American middle class and elite Asian values, portrayed in the film with stereotypical exaggeration. Eventually, the movie closes with a typical Hollywood happy ending, with acceptance of each other.

Having earned \$238 million worldwide (Box Office Mojo 2019) and nominations at the Golden Globe Awards 2019, the movie had noticeable impact on the Asian-American representation in Hollywood and especially in American society since most of the earnings came from the US box office. The movie, however, also created many controversies - about Asians, racism, role of women, globalization, and more. This issue of MGDR provides deeper insights into some of these, from several sharp and penetrating academic perspectives. Some of these debates concentrate on the lack of representation of Asian social diversity while others focus on the perceived American biases in the movie or the stereotypical representation of American and Asian values. The following section provides brief summaries of these debates from the scholarly contributions in this issue.

\section{Items in this MGDR Issue}

We kick off this issue with a piece by Reyes and Wyatt (2019), entitled "On the Banality of Transnational Film", geared toward locating the issues raised by the 'Crazy Rich Asians' film in the context of other recent similar 'groundbreaking' films (in terms of 'representation') as well as in the general history of how Hollywood globalized. Although this could have been (and nearly is) an article, we have decided, editorially, to feature it as a Dialogue contribution, in the hope of generating continued further interest and perspectives - yes, we are inviting these, for editorial consideration - on the issues raised in the Reyes and Wyatt essay. Reyes and Wyatt note that "... global blockbusters like Black Panther (2018) and Crazy Rich Asians (2018) create disturbances among critics and firms forced to wonder if such ripples of diversity will become waves of new 
cinema wiping out the hegemony of Hollywood and the global West". Using evidence from these two as well as a few other movies, with similar 'groundbreaking representation' efforts, the authors theorize that a transnational aesthetic for global blockbusters - rooted in the marketing systems and global political-cultural economy of films - limits the ripples of diversity and representation. They do not see 'Crazy Rich Asians' or similar Hollywood offerings able to transcend the "banal cinema of Americanized nothingness".

Three insightful reviews of the 'Crazy Rich Asian' film follow the introductory piece by Reyes and Wyatt, each reviewer focusing on how the film affects the arc of globalization, at least in terms of filmic representations. In the introduction of her review of Crazy Rich Asians (2018), Zhao (2019) makes a fine summary of the storyline and questions how the movie has become a controversial case on diversity representation. Considering the rise of Asia, particularly China as a new global economic superpower, the author finds that the film was timely. She discusses - in detail - how it became a symbol of the anti-whitewashing campaign that originated in Hollywood. Zhao, however, also points at the criticisms about the film's inadequacy in representing Asian social diversity. According to the author, "for the non-Asian-American audience, Crazy Rich Asians (2018) opportunely produced a visceral representation of the new 'other', culturally exotic and outrageously rich (p.3)." Zhao criticizes the film as not attending to the sociocultural differences in Asia and representing only the super-rich minority.

In the second review of the movie, Vijay (2019) takes a different stance compared to other reviewers, by underlining the constant duel between Asian and American values manifested in the movie with American values often winning out. The author argues that the film reproduces discourse of Orientalism and "the American and Asian binaries deployed in the film are falsely reductive (p.7)." As a second element entangled with the East/West motif, Vijay points to the dominant neoliberal feminist identity in the movie - emphasizing individual drive and entrepreneurialism. Moreover, as a third element, in a vein similar to Zhao (2019), she draws attention to the lack of representation of sociocultural diversity in Asian culture, especially the invisibility of the non-elite, and of the non-Chinese ethnic groups.

The third review is by Giana Eckhardt and Finola Kerrigan. Eckhardt and Kerrigan's (2019) review also examines the storyline and the film's reception in the West and in Asia, offering insight into contemporary globalization debates and the complexities of immigration, and how these issues and debates are perceived and changed over time. The authors 
argue that the film offers a critique of the American dream, emphasizing history and lineage, ideas that are valued higher in Asian culture. "While in many Hollywood films, the US and American lifestyle are depicted as aspirational, this is not the case in CRA (p.4)," the authors state. Accordingly, they wonder if the US supremacy over popular culture is now being challenged through this film (for more on this, in the pages of this journal, see the 2018 reviews of 'Black Panther' by Bowles and by Eckhardt). Noting that the film mainly focuses on the global Chinese elite diaspora experience, Eckhardt and Kerrigan (2019) also recognize the lack of social representation in the movie. They also argue, however, that the film is complex particularly in terms of the valorization of conspicuous consumption in Asian culture. In this sense, they leave the readers with possibilities for further research and exploration.

\section{Some Postscript Notes on the CRA Movie}

Following the release of 'Crazy Rich Asians', there have been some controversies in Hollywood. Adele Lim, a co-writer of the CRA film script, in follow-up projects, was offered a salary that was a fraction of the salary of the white co-writer (and she quit) (Helmore 2019). As noted by some of the authors in this issue, CRA was not a commercial success in China because the people saw the protagonist Rachel as a "race traitor". By contrast, "The Farewell", an independent film - set in Asia, indeed in China - starring the actress Lulu Wang (who played a comedic role in CRA, under the screen name "Akwafina") is proving to be bigger success in indie film festivals as well as in China (Aroesti 2019). All this points to the need for the dialogues of globalization, films, and markets to continue - race, representation, ethnicity, migration, inequality, prejudice, stereotyping, etc. are not going away anytime soon. We hope researchers will continue to explore these topics, and consider MGDR as a forum to present their ideas. 


\section{References}

Aroesti, Rachel (2019), "Awkwafina on Race and Hollywood: 'Growing Up, I Latched on to Strong Asian-American Idols,"' The Guardian, September 7, (accessed on September 10, 2019), [available at: https://www.theguardian.com/film/2019/sep/07/awkwafina-farewellcrazy-rich-asians-oceans-8-nora-lum]

Black Panther (2018), Director: Ryan Coogler. Writers: Ryan Coogler and Joe Robert Cole. Distributed by Marvel Studios, Feb. 16, 2018.

Boje, David M. (2019), "Water Avengers and their Endgame," Markets, Globalization \& Development Review, forthcoming.

Box Office Mojo (2019), Crazy Rich Asians, (accessed on November 21, 2019), [available at: http://bit.ly/CRA-Mojo1].

Bowles, Terri P. (2018), "Diasporadical: In Ryan Coogler's 'Black Panther,' Family Secrets, Cultural Alienation and Black Love," Markets, Globalization \& Development Review, 3 (2), Article 7. https://www.doi.org/10.23860/MGDR-2018-03-02-07

Crazy Rich Asians (2018), Director: Jon M. Chu. Writers: Peter Chiarelli, Adele Lim and Kevin Kwan. Distributed by Warner Bros. Entertainment Inc., August 15, 2018.

Eckhardt, Giana M. (2018), "Black Panther: Thrills, Postcolonial Discourse, and Blacktopia," Markets, Globalization \& Development Review, 3 (2), Article 6. https://www.doi.org/10.23860/MGDR2018-03-02-06

Eckhardt, Giana M. and Finola Kerrigan (2019), "Crazy Rich Asians: A Tale of Immigration, Globalization and Consumption in East Asia," Markets, Globalization \& Development Review, 4 (3), Article 5. https://www.doi.org/10.23860/MGDR-2019-04-03-05

Hazera, Alejandro (2017) "John Lee Hancock, The Founder (2016)," Markets, Globalization \& Development Review, 2 (4), Article 7. https://www.doi.org/10.23860/MGDR-2017-02-04-07

Helmore, Edward (2019), "Crazy Rich Asians Co-writer Quits After Being Offered Eighth of Writer's Salary," The Guardian, September 5, (accessed on September 5, 2019), [available at: https://www.theguardian.com/film/2019/sep/05/crazy-rich-asiansadele-lim-sequel-pay-disparity] 
Ozdamar-Ertekin, Zeynep (2017), "The True Cost: The Bitter Truth Behind Fast Fashion," Markets, Globalization \& Development Review, 2 (3), Article 7. https://www.doi.org/10.23860/MGDR-2017-02-03-07

Reyes, Ian and Justin Wyatt (2019), "On the Banality of Transnational Film," Markets, Globalization \& Development Review, 4 (3), Article 2. https://www.doi.org/10.23860/MGDR-2019-04-03-02

Vijay, Devi (2019), "Crazy Rich Asians: Exploring Discourses of Orientalism, Neoliberal Feminism, Privilege and Inequality," Markets, Globalization \& Development Review, 4 (4), Article 5. https://www.doi.org/10.23860/MGDR-2019-04-03-04

Zhao, Yikun (2019), "Crazy Rich Asians: When Representation Becomes Controversial," Markets, Globalization \& Development Review, 4 (3) Article 3. https://www.doi.org/10.23860/MGDR-2019-04-03-03 